\title{
On the North-West Borders of Roman Empire 73rd Annual Conference of the SIHDA in Edinburgh, UK, 3-7 September 2019
}

The annual conference of the Société Internationale Fernand de Visscher pour l'Histoire des Droits de l'Antiquité (SIHDA) is one of the most important events in the rank of the Roman law and laws of antiquity and the biggest meeting of Roman law scholars. This year the 73rd conference was hosted by The Centre for Legal History, Edinburgh Law School, The University of Edinburgh, UK. The main organizer was Paul du Plessis, professor of Roman Law at the University of Edinburgh, who was assisted by a team of competent and kind persons willing to help to the participants.

The general topic of the conference was Le droit et sa place dans le monde antique. However, the lecturers, as usual, had the possibility to choose the topic on their own, even if not closely connected with the general one.

Although the event itself took place from Tuesday, 3 September, to Saturday, 7 September, the registration was available from Monday, 2 September, which was very practical for those who came to Edinburgh on that day. The participants received violet rainproof bag with well-arranged programme containing the map and the photos of buildings where the venues were located. From the aesthetic point of view, it could be observed that the conference colour was violet, as the materials including USB and copybook contained in the package for participants as well as $e$. $g$. the lighting during the Scottish evening in Ghillie Dhu, were so harmonized.

A welcome reception opened the conference on Tuesday evening. It took place at the National museum of Scotland and beside the greetings with friends and meetings with new ones, it was possible to stroll in the Early Peoples Gallery admiring the artifacts from the period $8000 \mathrm{BC}$ to $1100 \mathrm{AD}$. The Gallery became for more than two hours a vivid place full of people interested in Roman law.

The following three days were full of interesting lectures, discussions and networking. The programme contained exactly 150 speeches, including an opening session at 10 a.m. in the Playfair Library in the South Side of Old College. The North Side of Old College hosted all the regular sessions in the teaching room 01, 02, 03, 06 and 07. Notwithstanding the antique look of the exterior of the University, the interior is highly new, with modern technique in the teaching rooms, and even with the touch screens before the rooms where the programme of the day was on display.

On Wednesday and Friday there were three sessions during the day on the programme while on Thursday the participants could attend four sessions. Usually, five papers were 
presented in different rooms at the same time. Therefore, the participants might have chosen the paper most relevant for them. Each lecturer had 30 minutes for his or her presentation and subsequent discussion. The time limit was strictly followed and guarded by the chairs of the sessions.

The official languages of the conference are traditionally English, French, German, Italian and Spanish. As expected, most of the papers were presented in English, other languages were represented in one or two dozen of speeches. The scholars represented the following countries: Austria, Belgium, Bosnia and Herzegovina, Bulgaria, Canada, Chile, Colombia, Croatia, Czech Republic, Estonia, Finland, France, Germany, Greece, Guatemala, Hungary, Italy, Israel, Japan, Netherlands, Poland, Portugal, Romania, Russia, Serbia, South Africa, Spain, Switzerland, Turkey, United Kingdom, United States of America. Hence, the conference is a global event attended by lecturers from all over the world Europe, America, Asia and Africa. The topics of the papers were dedicated to Roman Law, as well as to other laws of antiquity, and to comparative overviews and analysis of reception of certain institutes to modern legal systems.

Lecturers from the Czech Republic, two from Charles University, Prague, and one from Masaryk University, Brno, presented on Wednesday, 4 September. At first, Radek Černoch (Brno) held a paper "The Importance of Having an Heir" in the morning session. In his speech he focused on the role of the heir who replaced the deceased in all relations as the universal successor and thus he received not only the property rights, but also the duty to execute the private cult. Having an heir was important not only for the heir himself but for other persons as well - at the first place for the deceased, the creditors and the legatees. Marek Novák (Prague) dedicated his paper to the comparative topic: "The Influence of Roman Law on the Concept of Possession in Czech Civil Law". At the beginning, he described to his audience the recent development of Czech civil law, as the "new" Czech Civil Code based on the reception of Roman law came into force on 1 January 2014. However, it only allows to possess a right, which is a concept somehow different from the Roman law view. He analysed the influence of Roman law on the concept of possession held by Czech legal regulation, with respect to the object of possession. Kamila Stloukalová (Prague) focused herself on the extent of the disposition rights mortis causa of the head of the family in the period of the Twelve Tables in the paper called "Familiapecuniaque and the Pater familias' Disposal with the Property in the Early Times of the Roman Empire". The core of the paper was an examination of testamentary and intestate succession according to the decemviral legislation, of the calate testament, mancipatio familiae and its development into the mancipatory will and interpretation of the terms familia and pecunia. The following discussion was dedicated mainly to the latter issue.

The programme continued even after the lectures. On Wednesday, we participated to the reception and concert in 'The Quad' in the Old College. Thursday evening provided the real Scottish experience as we could have tasted the typical scotch meal - haggis with mashed potatoes and turnip, and could have enjoyed the traditional Scottish Ceilidh (music and dance).

Closing remarks were held on Friday afternoon, chaired by Jean-François Gerkens. As usual, the speeches in the memories of the deceased in the previous year were held (for Hans Ankum, Filippo Gallo, Karl Hackl, Tony Honoré, Daniela Piatelli, Peter Pieler, Alan Watson). Patrizio Carvajal and Carlos Amunátegui-Perelló from Pontificia Univesi- 
dad Católica de Chile presented very well-prepared invitation for the 74th SIHDA conference which will take place in Santiago de Chile, untraditionally, but not unreasonably in 5-9 January 2021, as this season is summer in Latin America. The topic chosen by the organizers is Mundus et commercium. The following conference will be partly in Brussels and in Gent with the topic "Law and Religion(s)". The Gala Dinner in the Balmoral Hotel ended the official part of the conference.

On Saturday we went by bus on the excursion to Vindolanda, Roman fort and town with stunning excavations and museum, and to Housesteads, Roman fortress by the Hadrian's Wall, with nice panoramic views.

The participants spent wonderful week at perfectly organized event among the amazing group of scholars from the countries from all over the world, establishing new networks and friendships, discussing the topics of our interest and obtaining suggestions and impulses for further scientific research.

Kamila Stloukalová

doi: 10.14712/2464689X.2019.46 